\title{
Effects of College Roommate Relationships on Student Development at a Private University, Southern Nigeria
}

\section{Dare Ojo, Omonijo}

Corresponding Author, Department of Sociology, Covenant University, P. M. B. 1023, Ota, Southwest Nigeria E-mail: oluwadare.omonijo@covenantuniversity.edu.ng

Michael Chibuzor, Anyaegbunam Department of Psychology, Nnamdi Azikiwe University,P.M.B 5025, Awka, Anambra State, Southeast Nigeria

Obiajulu Anthony Ugochukwu, Nnedum

Department of Psychology, Nnamdi Azikiwe University, P.M.B.5025 Awka, Anambra State, Southeast Nigeria

\section{Bernard Chukwukelue, Chine}

Department of Psychology, Faculty of Social Sciences, Nnamdi Azikiwe University P.M.B 5025, Awka, Anambra State, Southeast Nigeria

Omolola Abidemi, Rotimi

Department of Psychology, Covenant University, P.M.B. 1023, Ota, Ogun-State, Southwest Nigeria, Africa

Doi:10.5901/mjss.2015.v6n6s1p506

\section{Abstract}

This paper examined the effect of roommate relationships on students' development in a selected university campus. It used questionnaire to collect data from 470 respondents in a faith based university, Ota, Ogun State Nigeria. The study engaged Spearman's correlation method to test hypotheses formulated for the study at 0.01 level of significance. The study found a correlation between roommate relationship and students' academic performance and students' spiritual life. The study equally found a correlation between roommate relationships and involvement of students in social vices. Moreover, the study discovered correlation between roommate relationships and students emotional stability. Lastly, the study found a correlation between roommate relationships and student resource management.

Keywords: Effects, College, Roommate, Relationships

\section{Introduction}

Research on student development in higher education system in many developed nations Evans, Deanna and DiBrito, (1998) is not restricted to academic activities; diverse issues relating to hall of residence are also involved (Shelton, Nicole, Tessa and Trail 2010; McCorkle and Mason, 2009; Hanasonso and Nadler, 2012). Thus, problems relating to students campus residential settings have been of interest to many researchers, most especially human resource practitioners, Social Psychologists, Sociologists and scholars in humanities etc, in these societies for decades.

Despite the prevalence of a large body of literature on college roommate relationships in developed nations, literature on roommate relationships among tertiary students is very scanty in sub-Sahara Africa (SSA). The dearth of knowledge in this area in Nigerian higher institutions of learning is precarious and it is traceable to the poor-state-of- theart-facilities, which have been hindering effective learning. The most crucial aspect of these facilities as related to this study is insufficient accommodation for students. Where accommodation is available, it usually is poorly maintained and managed Omonijo, Uche, Rotimi and Nwadialor, (2014). due to poor funding of higher education Oweh (2013) and prevalence of endemic corruption in higher institutions. Consequently, the management of higher education system resorted to 'private developer policy on students' residential matters' (Edukugho, 2006) in order to make provisions for 
students' accommodation without any financial implication on the institution.

This policy, to a greater extent, encourages individual members of the society to build hostels for students. The practice has become pronounced in the Nigerian public tertiary institutions (Ubong, 2001; Onyike and Uche, 2010; Aluko, 2011; Alaka, Pat-mbano and Ewulum, 2012; Arisukwu, 2013) to the extent that most students live off-campus, in the midst of community dwellers where institutions of learning are established (Edukugho, 2006) instead of living on campus with their counterparts.

Since most Nigerian University students stay off campus (Edukugho, 2006), diverse social life issues hinging on students developments in hostels seem to have become hidden to academic exploration. The advent of private universities, with effective and efficient state-of-the-art-facilities for all students (undergraduate and postgraduate) has brought to the fore the importance of on-campus accommodation system on students development. However, since inception of private universities, studies on issues relating to students relationship in the hall of residence and their implications on student development have not been explored in academic literature. It is on this ground that this study was conceived. The study intends to discover the effects of college roommate relationships on students' development, which has been ignored in literature with a focus at a private university, Southern Nigeria.

Therefore, this study tries to investigate if the roommate relationship: (i) enhances students' academic performance, (ii) encourages students' spiritual life (iii) influence students' management of resources, (iv) supports students' emotional stability, (v) discourages social vices among students.

The study is divided into three major parts, namely: Introduction, literature review, theoretical insights, methodology, findings and discussion. The study ends with suggestion for further studies and concluding remarks inability of the Nigerian government to adequately provide decent accommodation for students

\subsection{Operational Definition of Terms}

College Hostel-a building that provide cheap accommodation and feeding for students

Roommate- a person who shares a room or apartment with another or others

Roommate Relationship- A type of connection that exists among students in the same room in higher institutions of learning.

Roommate Conflict- Misunderstanding among students who share the same room.

\section{Literature Review}

\subsection{Examination of Research on College Roommate Relationships}

First-hand experience show that interaction which arise either from students of the same background or of different backgrounds in the same room in the college hall of residence is regarded as roommate relationship, for a specified period In most cases, the lifestyle, habits / behaviours of students involved greatly differ. In some cases, this relationship involves fresh students who are entering higher education institutions for the first time. Such students apart from secondary school experience don't have any experience of residing with other persons. Thus, they will be acquitted with their roommates for the first time in life. In another development, older students, who are familiar with roommate relationship, are involved.

In each of the halls of residence on campus, students are grouped together in a room, either in twos or three or four, depending on their levels of education and sex of student. While 100 level students are allocated to a room in fours, older students in their sophomore and penultimate classes are allocated to a room in threes. In final year, two students are allocated to a room. In some universities, programme of study and level of students are generally used as criterions for room allocation.

In this arrangement, students do not determine the choice of their roommates. They are expected to accept students allocated to them and reside with them peacefully. Also, students are not permitted to influence room allocation. Although, students who are having challenges such as health, social, spiritual, moral are often put into consideration in the process of room allocation, but preferential treatment which is often the case being used in the public sector higher education to allocation of rooms to students in few hostels available is strictly prohibited in the private sector. Also, selling of rooms to another student is strictly averse.

However, it is important to note that residing with roommates is clearly different from living with one's family members or relatives. One's family member may want to tolerate and accommodate indecent behaviour, bad habits etc from somebody, because of blood relationship but one's roommates may never be at home with such. Consequently, 
residing with roommates may lead to personality mismatch among students. In such a situation, conflict is bound to happen and in an institution where stringent rules apply to student conduct, students who indulge in conflict are often sanctioned. Such cases used to emerge from a little misunderstanding among students in the same room or floor. Since most of them are adolescent, they lack maturity needed to manage such conflicts successfully. Therefore, anyone found guilty is either asked to withdrawal from the university or suspended or expelled.

Contrary to the above, previous studies show that student's roommate relationship is one of the most rewarding aspects of college life (McCorkle and Mason, 2009). It could ensure life friendship for students. It is possible for students to meet in the same room and a hall of residence and eventually become friends for life. Probably, this mighty has prompted many students to assume that their roommates will become their life friend, prior admission into higher institution. Nevertheless, roommate relationship could be different from friendship. It could involve sharing room with some students for a specific period without being in a strong relationship whereas friendship could signify a strong relation and it could last for a long time. Hence, the best roommates might not be student's best friends, but it is also possible for students to have their roommates as best friends.

It has also been argued that the quality of one's roommates' relationship predicts how well students will adjust to interpersonal experiences and their coping with academic demands (Erb, Keith, Jerome and Jeffrey, 2014). A student who has a bad roommate, who does not encourage academic activities, may be influenced to engage in less academic activities.

Besides, the quality of one roommate relationship as argued by Pittman \& Richmond, (2008) has a significant impact on the economic, spiritual and social life of other students. Students' ability to develop quality relationship at college according to Erb et al., (2014) predicts decreases in both internalizing and externalizing problem behaviours.

College roommate relationships are unique among students' interpersonal relationships because they live together. Roommates have frequent contact, negotiation of responsibilities, and compromises about the living environment (e.g., noise level, sleep/waking hours, visitors, and decor) (Erb et al., 2014). Students' roommates are typically the first nonfamily members and first people of equal with whom they live.

These "firsts" bring added challenges to students' abilities to get along with one another knowledge of roommate relationships and provide an overarching conceptualization.

\subsection{State of Knowledge on College Accommodation in Higher Education in Nigeria.}

For students to be able to read their books effectively and to pass their examinations very well and also be properly impacted for their future leadership roles, a comfortable accommodation is very crucial for them. Home defines peoples' comfort. If the home front is peaceful, the probability of advancement is real. But if the home front is not, no meaningful development is in view. It is on this note Aluko, (2011:1) submits

The importance of housing covers the entire aspects of human life. Primarily, it involves physical protection from hazards which ordinarily may be regarded as shelter but also provide the setting from many of the basic biological and social processes necessary to sustain life, which permitting the healthy growth and development of the mind. In all, housing as a unit of the environment of man, has a profound influence on the health, social behaviour, satisfaction and general welfare of the community.

Thus, it reflects the cultural, social and economic values of a society as it is the best physical and historical evidence of civilization in a country (Aluko, 2009).

In Nigeria, the original idea of hostel accommodation according to Egwunyenga, (2009) was to ensure good academic atmosphere for students. Given this, the first set of universities in Nigeria were able to build beautiful halls for both undergraduate and post graduate students Onyike and Uche, (2010) similar to developed societies. Therefore, hostel accommodation could be regarded as an integral part of higher education. This arrangement enhances team and communal spirit among students and encourages learning that is better served by proximity of classrooms, libraries (and laboratories) to halls of residence (Champion, 2004 cited in Onyike and Uche, 2010).

With time, however, students in Nigerian tertiary institutions began to face the challenge of inadequate hostel accommodation Aluko, (2011), because the population of students continues to grow without corresponding growth in the number of halls of residence and other physical facilities. Hence, the capacity of all the existing universities was overshot severally. Although the number of higher institutions has been on the increase (Obaka, 2008), since 1960, but maintenance Omonijo et al., (2014) and funding of these Universities has been a major problem. In respect of poor maintenance, Omonijo et al., (2014) claim that the application of 'not my father's business syndrome' to government 
properties and state affairs by many Nigerians has been keeping physical facilities in a dilapidated state. With this belief, any property belonging to government is been used indiscriminately.

In areas of funding World Bank, (2013) maintains that funding of education system in Nigeria is one of the worse in the world. This makes it impossible for higher institution managements to maintain the existing hostels and also build ones for students who are trooping into tertiary institutions every year.

It has equally been argued that high level of corruption in tertiary institutions in Nigeria, either at federal and state level has been responsible for poor and lack of a descent accommodation for students. The fund for maintaining physical facilities are often siphoned by the elites in these institutions in collaboration with their counterparts in government who put them there.

\subsection{Theoretical Insights}

Much work on reciprocity had been previously applied to social and economic systems of small communities (Gouldner, 1960; Oloko, 1982). In his explanation of reciprocity in cultural terms Oloko, (1982) argues that it specifically encourages the escalation of corruption among mankind. According to him, people reciprocate positive behaviour in the past with corrupt behavious. More recently, Omonijo, Anyaegbunam, Oludayo and Nnedum, (2015) associate the paradigm with the menace of political godfatherism in Nigeria. This shows that the theory is more related to social relationship and it could provide a plausible ground for explaining roommate relationship among students.

Reciprocity theory is largely associated with scholars such as (Adam, 1759; Ernst and Gächter 2000; Falk and Fischbacher, 2000). Most of these authors believe that reciprocity occurs in family and intimate relationships. They also emphasize that this type of relationship is by behaving positively without expecting quick and equivalent action in returns. By this principle, both parties may benefit from their positive relationship on the long run as argues by Adam, (1759) who describes reciprocity as kindness is the mother of kindness.

In Social Psychology, reciprocity theory connotes responding to a positive action with another positive action. However, it could be observed that the principle of reciprocity goes beyond positive action. It could also be a means rewarding a negative action received from another person in the past with another negative action in the present or anticipating retaliation in future, which corroborates Falk and Fischbacher, (2000) who believe that people reward kind actions and punish unkind attitudes. In other words, the theory explains the law of seed time and harvest as emphasize in (Genesis 8:22). Whatever a man sows, he reaps. He who therefore sows sparingly reaps sparingly while he who sows bountifully shall reap bountifully (2 Corinthians 7:10).

Dwelling on the above, reciprocity could be perceived as a social construct that has to do with responses to human behaviours. Naturally, people are frequently much nicer and much more cooperative to those who have shown them favour in the past. Conversely, people are always much more nasty and brutal in response to hostile actions they previously received from other persons. Previous studies mostly form Psychologists and Economists show that reciprocity is a strong determinant of human behaviours among mankind. Impressive literature in Sociology (ethnology and anthropology) also indicates the universal presence of reciprocal behaviours in every society. For instance, Gouldner, (1960: 171) believes that reciprocity is "no less universal and important element of culture than the incest taboo".

In the context of students' roommate relationships, therefore, reciprocity theory seems to be very useful in analysis. This is because relationship between one student and his roommates in the same room could bring about rewards and punishments in the nearest future. For instance, if a student is very kind to his roommates today, he or she may likely be compensated in the nearest future. His roommates may remember the memories of the good olden days. But if the roommates behave badly to his or her roommates, he or she may never benefit anything from such a roommate in life. On this note reciprocity theory could be regarded as acting and receiving relationships, but scholars such as Boaz, Benjamin, Converse, Jiunwen and Nicholas (2008) argued otherwise. They believed that reciprocity appears to operate on an exchange rate that assigns value to the meaning of events, in a fashion that encourages prosocial exchanges. Also, Cialdini, (2001) argues that reciprocating positive behaviours encourage and maintains prosocial behaviours.

In students' roommate relationships, some degree of reciprocity could emerge. Students could be willing to compromise or give aid to their roommates with the assurance that their roommates will reciprocate in future. The major challenge with this idea is that some of these students are still very young. Therefore, they may not consider the implication of their behaviours at this tender age. However, it is not impossible to assume that some of them will still remember to reciprocate past actions meted out them whenever the occasion avails. In sociology and other social science disciplines where constant interaction with one another on a daily basis is needed, favourable actions could easily be forgotten, but more often than not, negative behaviours linger on in people's memory. They serve as indelible marks that are very difficult to erase from peoples bodies. This is because positive attitudes tend to be reciprocated 
positively while the harmful ones provoke retribution (Vidmar, 2000)

Negative reciprocity in roommate relationship could occur when both or some of the students in a room fail to consider the interest of one another and it usually arises in hostile rooms where students are not living in harmony. If care is not taken, such a hostile relationship could lead to permanent enmity among students concerned in the nearest future. Moreover, this type of roommate relationship could damage personal and societal development. In this regard, Vidmar, (2000) says that reciprocating a negative behavior punishes and discourages antisocial actions. If this aspect could be intensified among students, definitely, it could stop them from engaging in bad relationships and it could lead to a peaceful co-existence in our society which corroborates Odeen, (2015) who claims that reciprocity plays an important role in generating cooperation and conflict resolution between states.

The view of Odeen, (2015) concurs with the vision of the institution under study, as it tends to encourage cooperation and peaceful resolution among students. This study intends to examine the reality of these issues in the university under study.

\section{Methods}

\subsection{Study Design}

This study adopts a descriptive survey research design.

\subsection{Population and Sample Size}

Student body represents the population of study. The total number in figure is 4,200 . Due to the resources at the researchers' disposal and time frame for a study of this nature, a sample of 470 respondents was drawn.

\subsection{Sample Techniques}

The university was divided into 23 departments. Each department produced respondents based on its population. In other words, the department with small number of students produced small sample while the department with large number of students produced large sample. Respondents were randomly selected from their departments afterwards.

\subsection{Research Instrument}

The questionnaire was used to collect data from the respondents. The instrument contains two sections-Section A and B. Section A comprises of 7 questions relating to socio-demographic characteristics of respondents while section B contained five questions connected with students roommates relationships. The section is an open ended type and provision was made for five options as indicated below:

1- Strongly agree

2- Agree

3- Undecided

4- Disagree

5- Strongly disagree

\subsection{Research Questions}

- What influence does roommate relationship have on students' academic performance?

- How does roommate relationship impact on students' spiritual life?

- What is the influence of roommate relationship on students' involvement in social vices?

- What is the influence of roommate relationship on emotional stability of students?

- What correlation does roommate relationship has on students' resource management?

\subsection{Research Hypotheses}

$\mathrm{H}_{1}$ : There is a relationship between roommate relationship and students' academic performance

$\mathrm{H}_{2}$ : There is a relationship between roommate relationship and students spiritual life.

$\mathrm{H}_{3}$ : there is correlation between roommate relationship and involvement of students in social vices

$\mathrm{H}_{4}$ : There is correlation between roommate relationship and students emotional stability

$\mathrm{H}_{5}$ : There is correlation between roommate relationship and student resource management 


\subsection{Reliability Test}

Table 1: Reliability Statistics

\begin{tabular}{|c|c|}
\hline Cronbach's Alpha & N of Items \\
\hline .999 & 21 \\
\hline
\end{tabular}

Source: Field Work, (2015)

In order to verify the level internal consistence for the research instrument the Cronbach's alpha test of internal consistency was employed as indicated in Table 1 . The test of reliability from the Cronbach's alpha statistic fall within the acceptance region of 0.999 with a total of 21 measured items which further indicates a high level of reliability for the research instrument used in the current study. Face and content validity was utilized and the research instrumented was subjected to validation by the combination of other experts and professionals in behavioral science research.

\subsection{Data Analysis}

Spearman coefficient correlation was used to test the hypotheses formulated to guide the process of this study.

Table 2: Response Rate

\begin{tabular}{|c|c|c|c|}
\hline SN & Questionnaires Distributed & Questionnaires Retrieved & $\%$ \\
\hline 1 & 500 & 470 & 90 \\
\hline
\end{tabular}

Source: Field Work, (2015)

Table 2 shows that out of 500 questionnaires distributed to respondents, researchers were able to collect 470 back, which represents $90 \%$

\subsection{Testing of Hypotheses}

In this study, five hypotheses were formulated. The acceptability or rejection of each of them was tested in this section.

\subsubsection{Hypothesis I}

$\mathrm{H}_{1}$ : There is correlation between roommate relationship and students' academic performance

Table 3: Test Statistics

\begin{tabular}{|c|c|c|c|c|c|}
\hline & & & $\begin{array}{l}\text { My roommates and I } \\
\text { engage in group } \\
\text { discussion every week }\end{array}$ & $\begin{array}{l}\text { My roommates and I read } \\
\text { together after class } \\
\text { discussions }\end{array}$ & $\begin{array}{l}\text { I used to do my class } \\
\text { assignments with my } \\
\text { roommates }\end{array}$ \\
\hline Spearman's rho & $\begin{array}{l}\text { My roommates and I } \\
\text { engage in group } \\
\text { discussion every week } \\
\text { My roommates and I } \\
\text { read together after class } \\
\text { discussions } \\
\text { I used to do my class } \\
\text { assignments with my } \\
\text { roommates }\end{array}$ & $\begin{array}{l}\text { Correlation } \\
\text { Coefficient } \\
\text { Sig. (2-tailed) } \\
\mathrm{N} \\
\text { Correlation } \\
\text { Coefficient } \\
\text { Sig. (2-tailed) } \\
\mathrm{N} \\
\text { Correlation } \\
\text { Coefficient } \\
\text { Sig. (2-tailed) } \\
\mathrm{N}\end{array}$ & $\begin{array}{l}1.000 \\
. \\
173 \\
.976^{* *} \\
.000 \\
173 \\
.963^{\text {** }} \\
.000 \\
173\end{array}$ & $\begin{array}{c}.976^{\star *} \\
.000 \\
173 \\
1.000 \\
. \\
173 \\
.978^{\star *} \\
.000 \\
173\end{array}$ & $\begin{array}{c}.963^{* *} \\
.000 \\
173 \\
.978^{* *} \\
.000 \\
173 \\
1.000 \\
. \\
173\end{array}$ \\
\hline
\end{tabular}

Source: Field Work, (2015) 
Given the estimated correlation result (0.976) between response variables "My roommates and I read together after class discussions" and "My roommates and I engage in group discussion every week" and I used to do my class assignments with my roommates and My roommates and I engage in group discussion every week at 0.963 all significant at 1 percent level. Therefore, the study proceeds to accept the hypothesis that says there is correlation between roommate relationship and students' academic performance and reject the null hypothesis.

The result of investigation presented above corroborate Erb, et al., (2014) who argue that predicts how well students will adjust to interpersonal experiences and their coping with academic demands. The result also demonstrates that students are in tune with the work ethic of the university under study which emphasizes team spiritedness among the students and staff. This emphasis might have encouraged students to be engaging in group academic discussion with their roommates. Although the study did not considered academic performance of each of the students in the sample, but the result to some extent has demonstrated that roommate relationship enhances academic performance.

\subsubsection{Hypothesis II}

$\mathrm{H}_{1}$ : There is correlation between roommate relationship and spiritual life of students

Table 4: Test Statistics

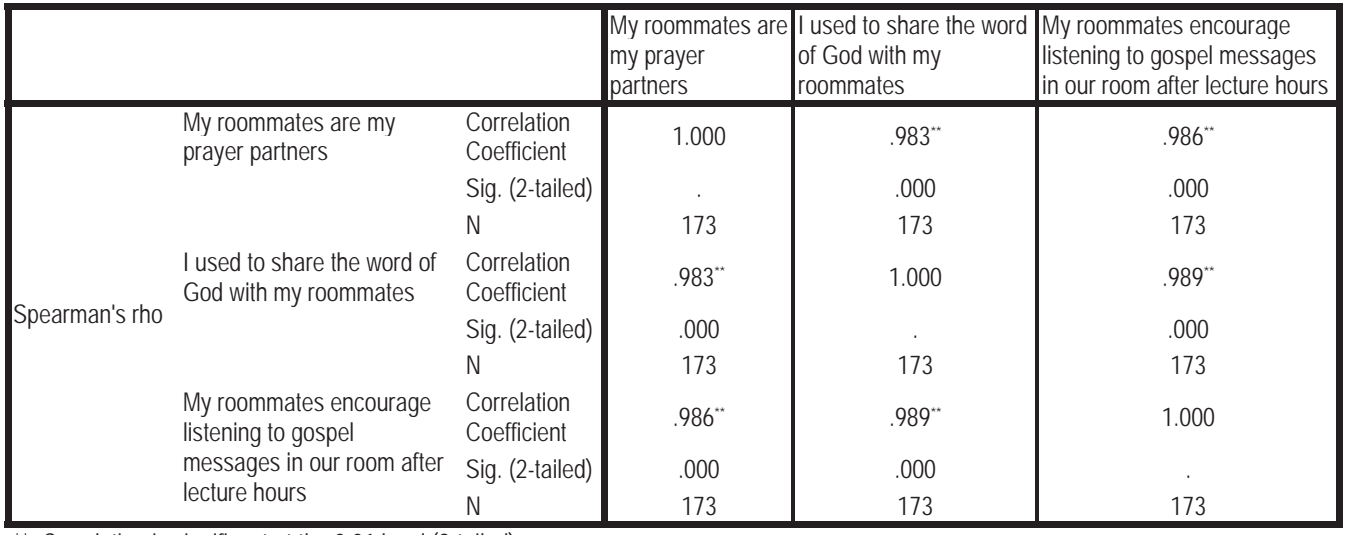

**. Correlation is significant at the 0.01 level (2-tailed).

Source: Field Work, (2015)

The evidence from the spearmen's correlation (0.983) for the response variable- my roommates are my prayer partners and "I used to share the word of God with my roommates with 1 percent level of significance and a positive correlation (0.986) with 1 percent level of significance for the two response variables "I used to share the word of God with my roommates and "My roommates encourage listening to gospel messages in our room after lecture hours" confirms the hypothesis that roommate relationship promotes spiritual life which suggests the rejection of the null hypothesis which says there is no correlation between roommate relationship and student spiritual life.

The result of investigation in Table 4 concurs with Pittman and Richmond, (2008) who submit that roommate relationship has a significant impact on the economic, spiritual and social life of other students.

The result presented above also demonstrates that students engage in spiritual exercises with their roommates. The finding here is not a surprise because the major core value of the institution under study is spirituality. It shows that students have imbibed the core value of spirituality and team spirit, which enable them to be praying together, reading Scriptures together and listening to messages either audio or video. Observing these Christian activities together can make one's spiritual life to blossom in and outside the university environment. 


\subsubsection{Hypothesis III}

$\mathrm{H}_{1}$ : Roommate relationship significantly influences the level of involvement in social vices

Table 5: Test Statistics

\begin{tabular}{|c|c|c|c|c|c|}
\hline & & & $\begin{array}{l}\text { My roommates don't watch } \\
\text { indecent movies }\end{array}$ & $\begin{array}{l}\text { My roommates don't drink } \\
\text { alcoholic drinks }\end{array}$ & $\begin{array}{l}\text { My roommates don't go } \\
\text { to disco parties }\end{array}$ \\
\hline \multirow{9}{*}{ Spearman's rho } & $\begin{array}{l}\text { My roommates don't } \\
\text { watch indecent movies }\end{array}$ & $\begin{array}{l}\text { Correlation } \\
\text { Coefficient }\end{array}$ & 1.000 & $.967^{\text {t* }}$ & $1.000^{* *}$ \\
\hline & & Sig. (2-tailed) & . & .000 & . \\
\hline & & $\mathrm{N}$ & 173 & 173 & 173 \\
\hline & $\begin{array}{l}\text { My roommates don't } \\
\text { drink alcoholic drinks }\end{array}$ & $\begin{array}{l}\text { Correlation } \\
\text { Coefficient }\end{array}$ & $.967^{\text {t* }}$ & 1.000 & $.967^{\star \star}$ \\
\hline & & Sig. (2-tailed) & .000 & . & .000 \\
\hline & & $\mathrm{N}$ & 173 & 173 & 173 \\
\hline & $\begin{array}{l}\text { My roommates don't go } \\
\text { to disco parties }\end{array}$ & $\begin{array}{l}\text { Correlation } \\
\text { Coefficient }\end{array}$ & $1.000^{* *}$ & $.967^{\text {t* }}$ & 1.000 \\
\hline & & Sig. (2-tailed) & ${ }^{\circ}$ & .000 & . \\
\hline & & $\mathrm{N}$ & 173 & 173 & 173 \\
\hline
\end{tabular}

**. Correlation is significant at the 0.01 level (2-tailed).

Source: Field Work, (2015)

The correlation co efficient (0.967) indicates a significant positive relationship between the response variable "My roommates don't watch indecent movies and "My roommates don't drink alcoholic drinks" at 1 percent level of significance. There also exist a perfect correlation significant at 0.01 levels for the response cases "My roommates don't watch indecent movies" and "My roommates don't go to disco parties". Therefore, we reject the null hypothesis that roommate relationship do not significantly influences the level of involvement in social vices accept the hypothesis which implies that roommate relationship do significantly influence the level of involvement in social vices.

The finding in Table 5, above is not surprising further consolidate the findings in Table 3 and Table 4. Since correlation between roommate relationships and academic performance and spiritual life of students have been confirmed respectively, certainly, there will be correlation between roommate relationship and involvement of students in social vices. It shows that studious and spiritual students do not engage in activities relating to social vices.

Moreover, the result of investigation in Table 5 goes to confirm differential association theory of Sutherland and Cressey, (1955) who maintain that how people act depends on how those around them desire them to act and how. Also, it shows that people deviate from or conform to norms depends on differences in whom they associate with (Sutherland and Cressey cited by Omonijo and Fadugba, 2011). Since those who are staying in the same room do not indulge in activities that can result in social vices, none of the members may become victim. Had it been that some of them were drinking alcoholic drinks, it would have been very easy to pressurize other to join in the act of drinking alcohol. 


\subsubsection{Hypothesis IV}

$\mathrm{H}_{1}$ : There is correlation between roommate relationship and emotional stability

Table 6: Test Statistics

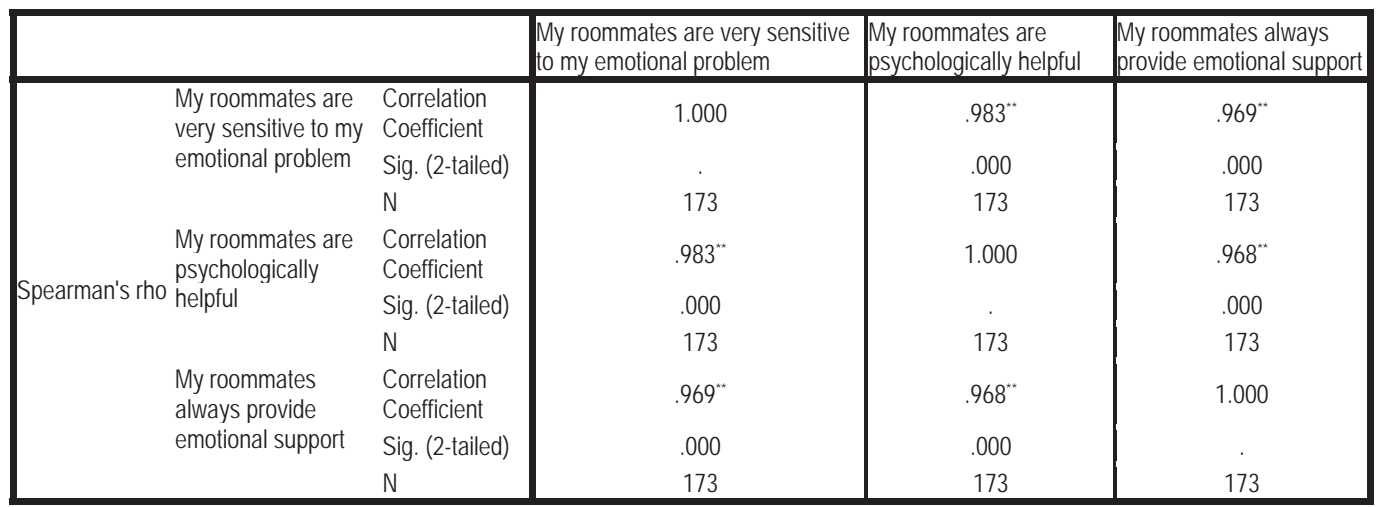

**. Correlation is significant at the 0.01 level (2-tailed).

Source: Field Work, (2015)

Evidence from the estimated correlation coefficient from Table 6 indicates a significant strong correlation (0.983) between the response variables "My roommates are very sensitive to my emotional problem" and "My roommates are psychologically helpful at 0.01 level of significance". Further evidence shows a statistically significant direct relationship for the response observations "My roommates are very sensitive to my emotional problem" and "My roommates always provide emotional support". Hence we could accept the study hypothesis that roommate relationship supports emotional stability while we discard the null hypothesis that roommate relationship does not support emotional stability.

If roommates are not concerned about their welfare they will not be sensitive to one another. Therefore, it would be very difficult to assist themselves. On campus, students are often told to always be their brother's keeper and it must have been responsible for our finding here.

\subsubsection{Hypothesis $V$}

$\mathrm{H}_{1}$ : There is correlation roommate relationship and resources management

Table 7: Test statistics

\begin{tabular}{|c|c|c|c|c|c|}
\hline & & & $\begin{array}{l}\text { My roommates offer } \\
\text { financial assistance } \\
\text { whenever I am broke. }\end{array}$ & $\begin{array}{l}\text { My roommates do not } \\
\text { encourage extravagant } \\
\text { life }\end{array}$ & $\begin{array}{l}\text { My roommates don't } \\
\text { encourage waste of } \\
\text { resources }\end{array}$ \\
\hline Spearman's rho & $\begin{array}{l}\text { My roommates offer } \\
\text { financial assistance } \\
\text { whenever I am broke. } \\
\text { My roommates do not } \\
\text { encourage extravagant } \\
\text { life } \\
\text { My roommates don't } \\
\text { encourage waste of } \\
\text { resources }\end{array}$ & $\begin{array}{l}\text { Correlation } \\
\text { Coefficient } \\
\text { Sig. (2-tailed) } \\
\text { N } \\
\text { Correlation } \\
\text { Coefficient } \\
\text { Sig. (2-tailed) } \\
\text { N } \\
\text { Correlation } \\
\text { Coefficient } \\
\text { Sig. (2-tailed) } \\
\text { N }\end{array}$ & $\begin{array}{c}1.000 \\
. \\
173 \\
.980^{\star \star} \\
.000 \\
173 \\
.969^{* \star} \\
.000 \\
173\end{array}$ & $\begin{array}{c}.980^{* *} \\
.000 \\
173 \\
1.000 \\
. \\
173 \\
.987^{\star \star} \\
.000 \\
173\end{array}$ & $\begin{array}{c}.969^{* *} \\
.000 \\
173 \\
.987^{\text {** }} \\
.000 \\
173 \\
1.000 \\
. \\
173\end{array}$ \\
\hline
\end{tabular}

**. Correlation is significant at the 0.01 level (2-tailed).

Source: Field Work, (2015) 
The analysis of the correlation result in Table 7 revealed a significance positive relationship (0.980) between the response variables "My roommates offer financial assistance whenever I am broke" and "My roommates do not encourage extravagant life" at 0.01 levels of significance. There also exists a strong significant correlation (0.969) between the response variables "My roommates offer financial assistance whenever I am broke" and "My roommates don't encourage waste of resources" at 0.01 significant levels. We could therefore conclude that there is a significant relation and between roommate relationship and resource management, which led to the acceptance of the hypothesis that there is correlation between roommate relationship and student resources management leading to rejection of the hypothesis.

The finding in Table 6 above confirms Pittman \& Richmond, (2008) who conclude that the quality of one roommate relationship has a significant impact on the economic life of students. This shows that a student who resides with students who are prudent in spending tends to be prudent in his spending life. Such a student may know how to manage his or her resources rather than squandering it.

The result also shows that students are in line with the culture of the university which discourages extravagant life and encourage proper management of resources among staff and students.

\section{Summary of Findings}

This study found correlation not only between roommate relationship and students' academic performance but also students' spiritual life, students' involvement in social vices, emotional life and management of resources.

\subsection{Conclusion}

This study concludes that roommate relationship enhances student development academically, spiritually, emotionally, economically and socially.

\section{Acknowledgements}

This research was supported by the Covenant University Centre for Research, Innovation and Development, (CUCRID), Ota, Ogun State, Africa.

\section{References}

Adams, J.S. (1759). Inequity in social exchange. In: Berkowitz, L. (Ed.), In: Advances in Experimental Psychology, vol. 2. Academic Press, New York, pp. 267-299

Alaka, I. N.; Pat-mbano, E. C.; Ewulum, N. J. (2012). Contributions of Private Hostel Providers to Housing Needs of Imo State University Students, at Ugwuorji-Owerri Nigeria. Canadian Social Science, 8(2):

Arisukwu, O. C. (2013). Cohabitation Among University of Ibadan Undergraduate Students. Research on Humanities and Social Sciences, 3 (5): 185-192

Aluko, O. (2009). Housing and Urban Development in Nigeria, Kins, Ibadan

Aluko, O. E. (2011). The Assessment of Housing Situation among Students in the University of Lagos. African Research Review- An International Multi-Disciplinary Journal, 5 (3): 104-118

Boaz, K., Benjamin, A. C., Jiunwen, W and Nicholas E. (2008). Reciprocity Is Not Give and Take Asymmetric Reciprocity to Positive and Negative Acts. Association for Psychological Science, 19(12): 280-2806

Cialdini, R.B. (2001). Influence: Science and Practice. Boston: Allyn \& Bacon

Covenant University, (2004). Staff Handbook and Condition of Service. Ota: Dominion Printing Press.

Covenant University (2014). Student Handbook. Ota: Dominion Printing Press.

Evans, N. J., Deanna, S. F and DiBrito, F. (1998). Student development in college: theory, research, and practice. San Francisco: Jossey-Bass Publishers, 1998. Print.

Edukugbo E. (2006). Moving Universities System Forward: Challenges Involved. Vanguard Newspaper, Daily, January 26th, P. 17.

Egwunyenga, E. J. (2009). Room-Mates Conflicts in Nigerian Universities: Causes and Management Strategies. Journal of Human Ecology, 27(2): 123-127

Ernst, F and Gächter, S. (2000). "Fairness and Retaliation: The Economics of Reciprocity". Journal of Economic Perspectives, 14 (3): 159-181.

Falk, A and Fischbacher, S. (2000). A Theory of Reciprocity. Working Paper Series 6. Institute of Empirical Research in Economics: University of Zurich

Gouldner, A. (1960). The Law of Reciprocity. American Sociological Review, 25, 161-178 
Hanasonso, L. K and Nadler, L. B. (2012). A Dialectical Approach to Rethinking Roommate Relationships. Journal of College Student Development, 53(5): 623-635

McCorkle, S and Mason, S. G. (2009). Conflict in Residence Halls: A Preliminary Study of the Efficacy of Roommate Negotiations to Reduce Roommate Conflict. Department of Public Policy and Administration, Public Policy and Administration Faculty Publications and Presentations. Boise State University Scholar Works

Obaka D. (2008). Current challenges for Nigerian students: tertiary education in Nigeria. Education Credential Evaluators Inc

Odeen, D. (2015). 41. Reciprocity in international relations. Available on https://odeenishmaeldiplomacy.wordpress.com/2013/08/19/41reciprocity-in-international-relations/

Oloko, T. (1982). Wither Nigeria; 20 Unresolved Problems About Nigeria. Lagos: Daily Times Limited

Omonijo D. O, Fadugba O. A. (2011). Parental Influence in Escalation of Examination Malpractices in Nigeria. European Journal of Social Science; 19(2):297-307

Omonijo, D. O., Uche, O. O. C., Rotimi, O. A and K. L. Nwadialor. (2014). Social Analysis of Moral Malpractice Challenging Education Sector in Nigeria. British Journal of Education, Society \& Behavioural Science; 4(7): 965-986.

Omonijo, D. O., Nnedum, O. A. U., Oludayo, O. A and Anyaegbunnam, M. C. (2015). The Menace of Political Godfatherism as a Factor in the Underdevelopment of Nigeria: Justifying Rostow's Thesis. European Journal of Economics, Finance and Administrative Sciences. In Press.

Onyike, J. A and Uche, O. N. (2010). An Assessment of the Management of the Students' Hostels of Tertiary Institutions in Owerri, Imo State. Tropical Built Environment Journal (TBEJ), 1(1): 1-10

Oweh, I. (2013). A case for better educational funding in Nigeria. Daily Independence., Jan. $28^{\text {th }}$. Available on http://dailyindependentnig. com/2013/01/a-case-for-better-educational-funding-in-nigeria/

Popelka, D.M. (1994). Residence Hall Retention: Factors That Influence an Upperclassman's Choice of Housing. Lowa State University. Unpublished PhD Thesis.

Shelton, J., Nicole. West, Tessa V, Trail, Thomas E. (2010). Concerns about appearing prejudiced: Implications for anxiety during daily interracial interactions. Group Processes \& Intergroup Relations, 13(3): 329-344,

Sutherland, E and D. Cressey, (1955). Principles of Criminology. J B Lippincott Company, Philadelphia

The Holy Bible, (2011). King James Version. China: Hendrickson Marketing, LLC.

Ubong, B. (2001). Pupil personnel management in school: A new emphasis under the UBE scheme. Ahmadu Bello University Journal of Education, Legal, and Management Studies. 1 (2). 13

Vidmar, N. (2000). Retribution and revenge. In J. Sanders \& V.L.Hamilton (Eds.), Handbook of justice research in law (pp. 31-63). New York: Kluwer Academic/Plenum

World Bank. (2012). Some selected countries annual budgetary allocation on education. Accessed on August 29th 2013. Available on<(www.impactng.com/impact/news_one.php?article=63>. 